\title{
The Economic Impact of the Suitcase Trade on Foreign Trade: A Regional Analysis of the Laleli Market
}

\author{
Kenan Aydin $^{1}$, Lacin Idil Oztig ${ }^{2} \&$ Emrah Bulut ${ }^{1}$ \\ ${ }^{1}$ Department of Business, Yildiz Technical University, Istanbul, Turkey \\ ${ }^{2}$ Department of Political Science and International Relations, Yildiz Technical University, Istanbul, Turkey \\ Correspondence: Lacin Idil Oztig, Department of Political Science and International Relations, Yildiz Technical \\ University, Istanbul, 34220, Turkey. Tel: 90-383-67-30. E-mail: lacinidiltr@yahoo.com
}

Received: November 2, 2015

Accepted: January 21, 2016

Online Published: February 25, 2016

doi: 10.5539/ibr.v9n3p14

URL: http://dx.doi.org/10.5539/ibr.v9n3p14

\begin{abstract}
Previous studies have analyzed the suitcase trade from global, state-centric and local perspectives. While the first two categories of studies analyzed the economic impacts of the suitcase trade from global and state-centric perspectives, other studies analyzed the cultural implications of the suitcase trade. This is the first systematic study to analyze the economic impact of the emergence, increase and decrease of the suitcase trade on suitcase traders. Specifically, this study analyzes the dynamics of the suitcase trade between Turkey, the Russian Federation, the former Soviet Republics on foreign trade. Individuals from different sectors (wholesalers, retailers and manufacturers) constitute the target group of this study. Surveys and focus group interviews serve as our data. The data covers the period from 1990 to 2013. Surveys were completed by 257 people from firms which participated in the suitcase trade in the Laleli market-Turkish market place for the suitcase trade. Focus group interviews were conducted with 16 people in a conversational style. This exploratory study contributes to the body of empirical evidence by analyzing the changing dynamics of the suitcase trade. The study concludes with policy proposals to tackle local, regional and global challenges of the suitcase trade.
\end{abstract}

Keywords: suitcase trade, foreign trade, the Laleli market, transition economies, the Russian Federation

\section{Introduction}

While much of the literature analyzed the dynamics of transition economies after the collapse of the Soviet Union, relatively less attention is given to the suitcase trade which emerged during the transition period from a planned economy to a market economy. In the last decade, there has been an increased scholarly attention on the suitcase trade. These studies analyzed the suitcase trade from global, state-centric and local perspectives.

Suitcase trade is "a form of unrecorded (or under-recorded) international transactions in goods that is currently existent at the edges of formal trade" (International Monetary Fund [IMF], 1998, p. 6). In suitcase trade goods which are allowed for customs-free and tax free import are purchased in one country and brought across the border into another country in small packages such as luggage or bags. The goods are then sold in domestic market. In more sophisticated forms of the suitcase trade, goods are transported apart from their traders. The suitcase trade differs from other forms of trade with regard to the size of goods. In addition, it is independent of normal foreign trade. This trade is conducted without importers or exporters (International Monetary Fund, 1998). This study systematically analyzes the emergence, increase and decrease of the suitcase trade in Turkey based on the experience of suitcase traders. This study sheds light on the suitcase trade from a local perspective by analyzing views of participants who conducted trade in the Laleli market-Turkish market place for suitcase trade.

This is the first systematic study to analyze the economic impact of the emergence, increase and decrease of the suitcase trade on suitcase traders. This study maps out changing dynamics of the suitcase trade and challenges which Turkish suitcase traders face. This study is based on surveys and focus group interviews. Surveys were completed by 257 people from firms which conducted the suitcase trade in the Laleli market. Focus group interviews were conducted with 16 people. Individuals from different sectors (wholesalers, retailers and manufacturers) constituted the target group of this study. By analyzing the experience of suitcase traders, this paper offers important insights into informal trade in Turkey. 
The remainder of this paper is divided into 5 main sections. The second section briefly describes the historical episodes of the suitcase trade in Turkey. The third section provides a scholarly literature review of the suitcase trade. The fourth section provides an outline of the methodological framework. The fifth section forms the empirical part of the investigation. The final section summarizes the results and discusses their implications for business and government strategies.

\section{Historical Background of the Suitcase Trade in Turkey}

In Turkey, the suitcase trade started when passengers from Northern Cyprus started to sell the island's products in Turkey. At the start of the 1990s, the suitcase trade was used to export in Turkey. The liberalization of the Turkish trade regime in the 1980s and the collapse of the Soviet Republic in 1991 provided fertile ground for the emergence of the suitcase trade between the Russian Federation, the former Soviet Republics and Turkey. While Russia, the former Soviet Republics were mainly importers, Turkey was mainly an exporter in the suitcase trade.

Little official information is available on the suitcase trade between 1991 and 1996. In 1996, the IMF put pressure on the Turkish Central Bank to calculate the volume of the suitcase trade (Eder et al., 2003). Therefore, the official data on the suitcase trade is available from 1996 onwards. However, it should be noted that since the suitcase trade is an informal form of trade, official statistics might not reflect the real volume of the suitcase trade in Turkey. The suitcase trade might be much higher than indicated in official statistics. Although the official data might not reflect the real volume of the suitcase trade, it gives a snapshot of increases and decreases of the suitcase trade in certain periods

The right axis of Figure 1 shows the revenue of the suitcase trade (red pillar), total Turkish exports (blue pillar) and the share of the suitcase trade in total Turkish exports (green line) between 1996 and 2014. While the revenues of the suitcase trade in 1996 and 2014 are approximately the same (between 8 and 9 billon dollars), their percentages in total Turkish exports plummeted dramatically from 38\% in 1996 to $5.21 \%$ in 2014 (red line). This decrease is associated with an increase in total Turkish total exports from 1996 to 2014. While in 1996, total Turkish exports was 23.2 billion dollars, in 2014 it rose to 157.6 billion dollars.

More insights from the suitcase trade are revealed when the revenue of the suitcase trade is analyzed within three years periods. After 1996 the suitcase trade declined, and the most dramatic decline took place between 1996 and 1999. The suitcase trade declined from 8.9 billion to 5.9 billion dollars in 1997 and 3.7 billion dollars in 1998 . The suitcase trade reached its lowest level in 1999 at 2.26 billion dollars (Central Bank of the Republic of Turkey [CBRT], 2014). After 1999, the suitcase trade revenue fluctuated. The suitcase trade slightly increased from 2000 to 2002. In the following period, the turnover of suitcase trade went down. After 2005, the suitcase trade increased sharply in 2006 reaching 6.5 billion dollars. It moved steadily until the end of the 2008 and declined afterwards. The suitcase trade gradually increased from 2012 onwards reaching 8.63 billion dollars in 2014 (CBRT, 2014).

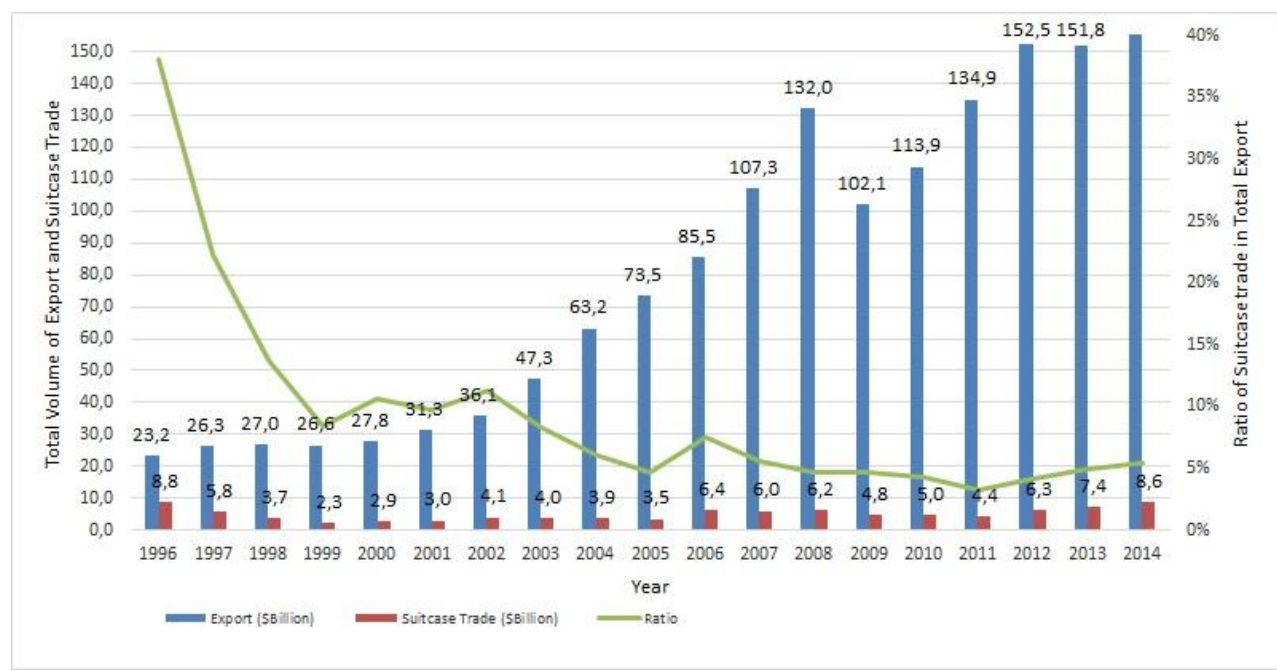

Figure 1. The development of the suitcase trade with total Turkish export

Source: Central Bank of Turkey (2014). 
There are a number of reasons behind changes in the dynamics of the suitcase trade. Russia's political and economic decisions on the suitcase trade give a partial explanation to the fluctuations of the suitcase trade over the years. Sharp devaluation of the rouble in the aftermath of the East Asian economic crisis in 1998 correlates with a sharp decline in the volume of the Turkish suitcase trade in Turkey. In 2006, Russia placed duties and weight restrictions on customs-free import of goods. While previously the maximum weight allowed for customs-free products was $50 \mathrm{~kg}$, it was decreased to $35 \mathrm{~kg}$. (Stammler-Gossmann, 2012). In 2010, after mutual talks between the then Prime Minister Recep Tayyip Erdoğan and President Vladimir Putin, Russia increased the maximum weight allowed for customs-free products to $100 \mathrm{~kg}$ and the maximum value allowed for these products from $\$ 1,000$ to $\$ 3,000$ (Yavuz, 2010).

As seen in the Figure 2, in line with a steady increase in total Turkish suitcase trade from 2012 to 2014, Turkey's suitcase trade with Russia in on the increase. While the suitcase trade with Russia amounted to 3.1 billion dollars in 2012, it rose to 4.2 billion dollars in 2014. The suitcase trade with Russia is the second most lucrative business after exports. The total revenue of the suitcase trade surpasses the revenue that Russian tourists bring. Interestingly, Russian-Turkish trade in this period displays a rising and a decreasing tendency. Turkish exports with Russia increased from 6.7 billion dollars to 7.billion dollars in 2013 and declined to 5.9 billion dollars in 2014. The decrease in Turkish exports with Russia is correlated with the shrinking of the world economy in 2014 To summarize, in the 2012-2014 period, in contrast to the fluctuating tendency of Turkish exports to Russia, Turkey's suitcase trade with Russia steadily increased.

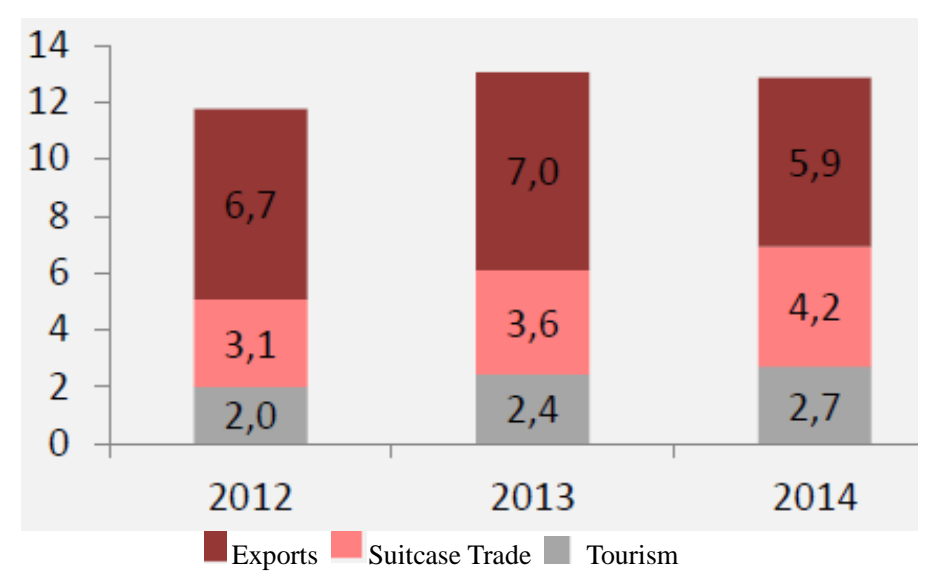

Figure 2. Economic relations with Russia in the Turkish current balance accounts on yearly basis (billion USD)

Source: Central Bank of Turkey (2014).

The decline of Russian economy due to the geopolitical and economical dynamics is expected to have a negative impact on the suitcase trade between Russia and Turkey. In addition, due to the interdependency between Russian economy and former Soviet Republics, the suitcase trade between Turkey and former Soviet Republics might also decline (CBRT, 2014).

Although the dynamics in Russia is an important determinant of the volume of the suitcase trade in Turkey, there are also other factors which have an impact on the emergence, increase and decrease of the suitcase trade. After reviewing factors and dynamics discussed in the scholarly literature which shed light on the process and the dynamics of the suitcase trade, we analyze how the changing dynamics of the suitcase trade has impacted on the suitcase traders.

\section{Literature Review}

Much of the economics and international business literature analyzed the dynamics of transition economies which depart from planned economies which focus on heavy industry to liberal economies which focus on global trade. A significant number of studies analyzed structural and policy reforms which lead to fully-fledged liberal market economy (Ahluwalia, 2002; Fischer \& Gelb, 1991; Kornai, 1986; Ramamurti, 2000; Baumol \& Strom, 2007; Naude', 2011; Nelson, 2008). Another important area of research within this body of literature concerned with the experience of firms in transitional periods (Gao et al., 2007; Rinaldi, 2008; Firth et al., 2015).

Strikingly, a few studies analyzed unregistered economic activities which are the by-products of transition economies. Kaufmann and Shleifer (1997) indicate that there is a significant increase in informal trade during 
transition periods from planned economies to liberal economies. In these transition periods, the inability to adapt to the market economy, the insufficient accumulation of capital and lack of free market policies are listed as factors which pave the way for the unregistered economy. On the other hand, it is stressed that countries with strong public institutions are less likely to witness unregistered economic activities. Schneider and Enste (2002) argue that ineffective taxation systems in transition economies trigger unregistered economic activities. Egbert (2006) and Stammler-Gossmann (2012) conclude that trade barriers and price differentials contribute to the emergence of informal trade. Holtom (2006) indicates that while the elimination of travel restrictions increases informal trade, travel restrictions thwart it.

In the last decade, increased scholarly attention has been paid to the suitcase trade. The academic literature on the suitcase trade can be grouped into three main categories. The first category of studies analyzes the globalized suitcase trade. According to these studies, the suitcase trade is a by-product of global trade. Eder et al. (2003) indicate that the global free market has changed consumption and production tendencies. In the aftermath of the collapse of the Soviet Union, trade was transformed with the emergence of new entrepreneurs. This transformation largely took place along the borders. In this transitional period, the suitcase trade emerged as an informal trade network which transcended borders. Similarly, Yükseker (2007) indicates that with the spread of Western-style fashion and images, Russian consumers wanted to buy Western products and this triggered the suitcase trade between Turkey and Russia.

The second category of studies analyzes the relationship between the suitcase trade and state economies. Duman ve Samadov (2003) associate the emergence of the suitcase trade with transition economies. Under the Soviet Union most resources were devoted to the defense and space industries, while consumption goods were largely neglected. After the collapse of the Soviet Union, the transition to a market economy began. Prices were liberalized with 1992 reforms and steps were taken with regards to the fiscal balance and institutional impediments to trade were abolished. Between 1992 and 1996, small and medium-scale state institutions were privatized. Following the transition period from a planned economy to a liberal economy, there were no monitoring mechanisms. In this context, the suitcase trade flourished as an informal trade network. This enabled Russian citizens to bring foreign goods to their country with low prices.

Kucukaltan (2006) notes that after China devalued its currency in 1994, Asian states such as South Korea, Thailand, Taiwan and Japan were negatively affected. The East Asian crisis also spread to Russia. Duman and Samadov (2003) argues that due to the East Asian crisis, oil and gas prices in the world decreased. The decrease in oil and gas prices had a significant impact on the Russian Federation whose economy relies primarily on energy exports. In order to increase its exports, Russia devalued its currency. As a consequence, buying foreign goods in Russia became expensive and resulted in a decrease in the volume of suitcase trade between Russia and Turkey.

Dansc1 (2008) argues that the collapse of distribution channels for trade due to the collapse of the planned economy is the main reason behind the growth of the suitcase trade. The collapse of trade regimes and state-controlled export and import systems in planned economies led to recession and increased the gap between public demand and state supply. The insufficiency of the distribution channels during the transition process from the planned economy to free-market economy encouraged many individuals to engage in unregistered economic activities with neighboring countries. In addition to this, a sudden decrease in the standard of living during the transition period resulted in the development of the suitcase trade as a survival strategy during economic necessity.

In a study done by Şahin, Yılmaz, and Atakan (2008), it is indicated that the change in the suitcase traders' route to China, India and Romania contributed to a decrease in suitcase trade between Russia and Turkey after 1998. In addition, it is stressed that the suitcase trade shows cyclical fluctuations. It is noted that the suitcase trade tends to increase in autumn and decrease in summer.

The third category of studies focuses on cultural dynamics. These studies indicate that the suitcase trade triggered the emergence of trust and a sense of community between sellers and buyers in the Laleli market. Yükseker (2004) argues that since the suitcase trade suffers from lack of legal frameworks, the suitcase traders aimed to decrease economic uncertainty. In order to maintain trade relationship in light of economic uncertainty, sellers in the Laleli market built trust with their trading partners.

Eder and Öz (2008) indicate that in the aftermath of the 1998 crisis, strategies with regards to the suitcase trade changed. Due to the crisis, half of shopkeepers in Laleli either went into bankruptcy or suffered a significant amount of material loss. In the aftermath of crisis, shopkeepers in Laleli changed their strategies by increasing the quality of their goods and started to sell goods in the market with competitive prices. In addition, informal 
credit and borrowing mechanisms have emerged. Although the 1998 crisis resulted in a loss of trust between suitcase traders and shopkeepers, the trade relationship between those who survived the crisis became long lasting. The survival of crisis with strategies such as price changes and credit and borrowing mechanisms demonstrated the adaptability of informal markets to external challenges.

In their subsequent study, Eder and Öz (2012) analyze suitcase trade within the framework of transnational community. They note that the suitcase trade, initially, suffered from fragility and uncertainty. Over time, a transnational community emerged in Laleli. In other words, the suitcase trade triggered the emergence of a community. A sense of belonging to a community explains why trade bonds were maintained in the Laleli market despite financial, political crises, and legal changes.

In summary, most studies in the scholarly literature analyzed the economic impact of the suitcase trade from a global or state-centric perspective. The first category of studies portrayed the suitcase trade as a by-product of the global market economy. The second category of studies analyzed the relationship between the suitcase trade and state economies. Other studies analyzed the cultural dimension of the suitcase trade. These studies explained how the suitcase trade led to the emergence of trust and a sense of community between suitcase traders. Little scholarly attention has been paid to the economic implications of the suitcase trade on suitcase traders. This study is the first systematic study to analyze how the changing dynamics of the suitcase trade in Turkey have impacted on suitcase traders.

\section{Methodology}

This study was conducted in Laleli located in the historical peninsula of Istanbul in which the suitcase trade takes place. The data provided in this study was compiled through surveys and focus group interviews. The data covers the period from 1990 to 2013. We preferred surveys and focus group interviews as research strategies due to the fact that official data and statistics do not cover all aspects of the suitcase trade which is conducted informally. By analyzing the response of participants, we aim to investigate the suitcase trade within its real-life context.

Informants in this study are suitcase traders. A year of experience in the Laleli market was a criterion for the selection of the participants. In the selection of participants for survey, particular attention was paid to the criteria of having trading experience of 15 or more years in the Laleli market. Experience of more than 20-25 years in the Laleli market was a major factor in selecting participants for focus group interviews.

Surveys were completed by 257 people from firms which participated in the suitcase trade in the Laleli area. In selection of participants, particular attention was paid to trade sector diversity. Among the 257 participants, 136 of them sold textiles, 36 of them sold cosmetics, 29 of them sold bags, 28 of them sold shoes and 28 of them sold accessories. Of the participants, 132 were wholesalers, 76 were retailers and 49 were manufacturers. Among the manufacturers, $65 \%$ soled textiles, $4 \%$ sold accessories, $8 \%$ sold shoes, $22 \%$ sold bags. Among wholesalers, $58 \%$ of them sold textile, $10 \%$ of them sold accessories, $5 \%$ of them sold shoes, $18 \%$ of them sold cosmetics. Among the retailers, $36 \%$ sold textile, $17 \%$ sold accessories, $16 \%$ sold shoes, $16 \%$ sold bags and $16 \%$ sold cosmetics. In surveys, participants were presented with questions regarding the periods in which the suitcase trade was high and low and sector (s) suffered most from the decline of the suitcase trade.

Focus group interviews were conducted with 16 people. Individuals from different trade areas (wholesalers, retailers and manufacturers) constituted the target group of this study. 4 of the participants were manufacturers and wholesalers, 7 of them were wholesalers, 3 of them were retailers and 2 of them were wholesalers and retailers. During the focus group interviews, 14 conversational questions were presented to participants. In order to map out the changing dynamics of the suitcase trade, questions largely focused on the countries with which the trade was conducted, the transportation and payment methods, the peak period of the suitcase trade, the impact of the suitcase trade's decline on different sectors and trade challenges leading to the suitcase trade's decline.

There are some methodological problems with regards to surveys and focus group interviews. Since questions cover the period from 1990 onwards, there might be inaccuracies due to poor recall. In order to increase the reliability of our analysis, we conducted surveys with 257 people. We displayed the percentages of negative or discrepant information in figures. With focus group interviews, we double-checked the information provided by surveys with detailed questions. While acknowledging the methodological limitations, we note that our study is an exploratory study about the suitcase trade. Although there might be inaccuracies due to poor recall regarding specific years, this study aims to shed light into the changing dynamics of the Laleli market and how this changing dynamics have impacted Turkish suitcase traders. 


\section{Empirical Results}

While findings of surveys provide a general insight into the suitcase trade in Turkey, findings of focus group interviews provide a more detailed picture. This section provides a qualitative description of the experience of Turkish suitcase traders. While the results of surveys are displayed in figures, the results of the focus group interviews are analyzed by sub-headings.

\subsection{Surveys}

The survey results are displayed in figures. Figure 3 shows participants' view about the periods in which the suitcase trade was high and low. According to the data, the period in which the suitcase trade was most active was between 1994 and 1997. The year most participants associate with high intensity of the suitcase trade is 1997. 257 respondents noted that the suitcase trade in 1997 was high. Only 12 respondents stated that the suitcase trade was low in 1997. A significant number of participants noted that the volume of the suitcase decreased after 1997. The year in which most associated with low intensity suitcase trade is 2013. 244 respondents stated that the suitcase trade was low in 2013. Only 8 respondents stated that the volume of the suitcase was high in 2013.

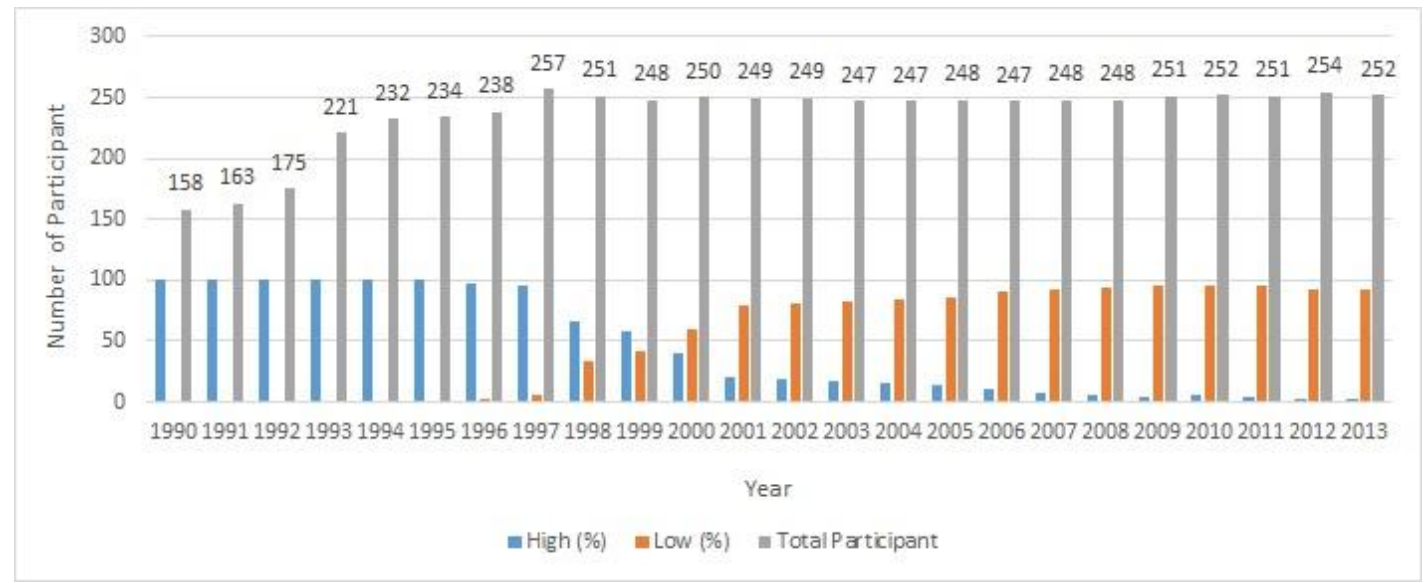

Figure 3. High and low percentage of period of the suitcase trade according to participants

Figure 4 shows participants' view about the reason behind the decline of the suitcase trade. $20 \%$ of participants indicated that cheap Chinese products decreased competitiveness of Turkish products and contributed to the decline of the suitcase trade. Other major reasons were listed as expensive cargo prices, sending low quality and expensive products, and national policies.

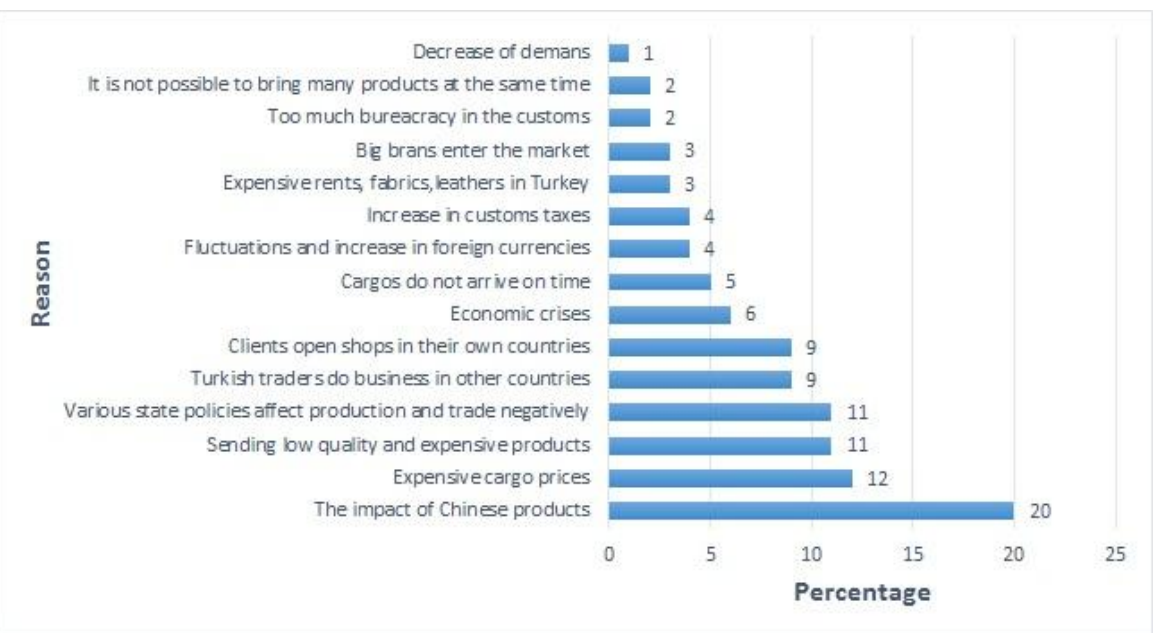

Figure 4. Reasons of the decline in the suitcase trade 
Figure 5 shows how the changing dynamics of the suitcase trade affected participants working in different trade areas. Participants were asked about whether the suitcase trade declined after 1997 . While $51 \%$ of manufacturers said it definitely decreased, $49 \%$ of manufacturers said it decreased. While $58 \%$ of wholesalers said it definitely decreased, $39 \%$ of wholesalers said it decreased. While $49 \%$ of retailers said it definitely decreased, $51 \%$ of retailers said it decreased. In sum, irrespective of their trade sectors, the majority of suitcase traders indicated that the suitcase trade declined after 1997.

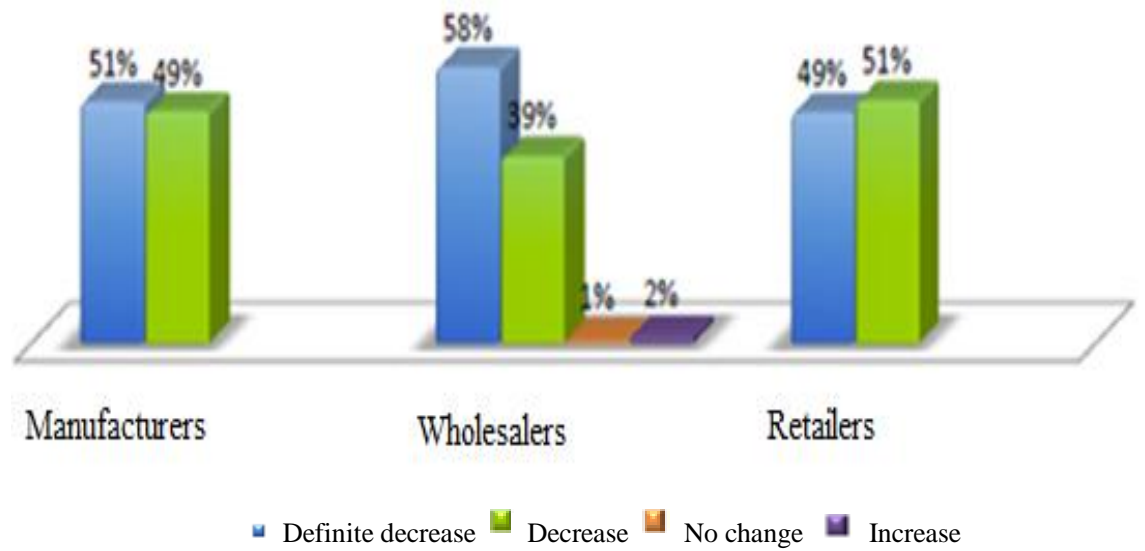

Figure 5. Dynamics of the suitcase trade according to participants

Figure 6 shows how the changing dynamics of the suitcase trade affected different trade sectors. Participants were asked about whether the suitcase trade declined after 1997. While almost half of the participants working in textile sector said it definitely decreased, another half of them said it decreased. All participants working in the accessories sector said the suitcase trade definitely decreased after 1997 . While $43 \%$ participants selling shoes said it definitely decreased, $57 \%$ of participants said it decreased. $67 \%$ participants selling cosmetics said definitely decreased, $33 \%$ said it decreased.

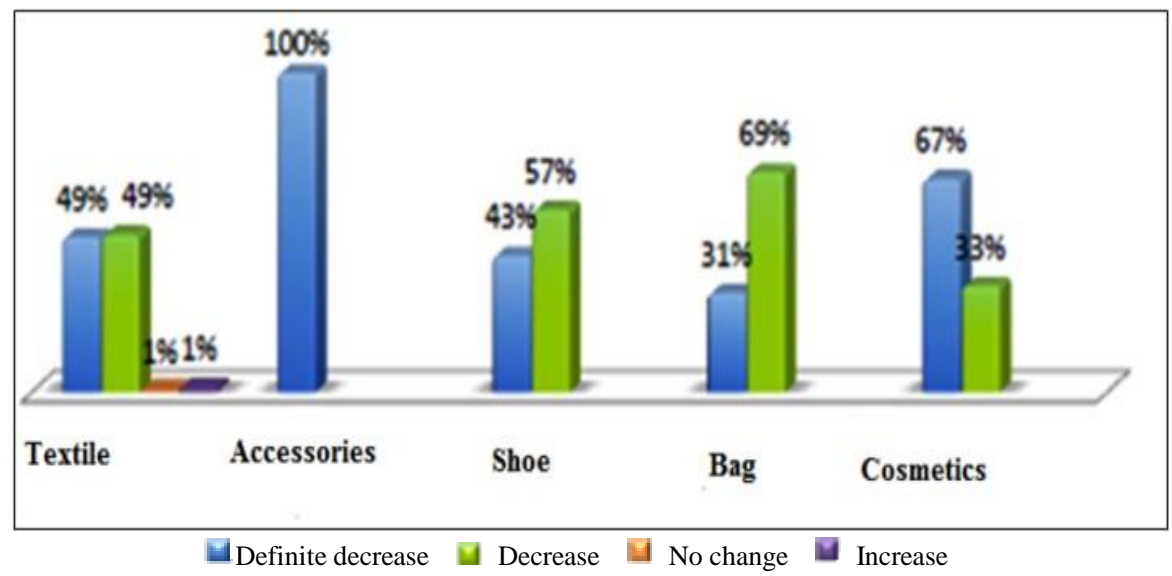

Figure 6. Effects of the dynamics of the suitcase trade on trade sectors according to participants

\subsection{Focus Group Interviews}

\subsubsection{Countries and Sectors in the Suitcase Trade}

According to the participants, when the suitcase trade first began, it focused on leather products such as bags, shoes and belts. As demand for the suitcase trade increased, trade products diversified. According to the participants, Russia ranked first in all sectors including textiles, accessories, bags, and cosmetics. The participants stressed that the sector which suffered most from the decline of the suitcase trade was the accessories sector. Other sectors were listed such as cosmetics, textiles, shoes and bags.

Participants were asked to list the 5 most important countries with regards to the suitcase trade before 1997. The 
countries with which the most suitcase trade was made were listed as the Russian Federation, Ukraine, Azerbaijan, Kazakhstan and Poland. 76.5\% participants noted that before 1997 most trade was made with Russia. They noted that after 1997 most suitcase trade was made with the Russian Federation, Ukraine, Kazakhstan, Tajikistan, Germany and Arab countries.

\subsubsection{The Changing Dynamics of the Suitcase Trade}

According to the participants the period in which the suitcase trade was most active was between 1994 and 1998 . The participants indicate that after Russia devalued its currency in 1998, many suitcase traders either went into bankruptcy. From the year 2000 onwards the market revived to a certain extent. However, since four years there has been a decline in the volume of the suitcase trade. The main reasons for the recent fall were listed as currency fluctuations, economic crises in neighboring countries and an increase in costs.

The participants stress that the suitcase trade was much more active before China was not producing. Products were manufactured around Laleli. Daily sales were high. Purchasing power was relatively high in comparison to today. The suitcase traders started their own manufacturing later on. The traders in this market attracted customers by establishing companies abroad. While before 1997 the Laleli traders manufactured 500-600 products daily, today a few products are manufactured in a week.

\subsubsection{The Processes of the Suitcase Trade}

Usually, in suitcase trade individuals buy goods by coming to a foreign country and taking these goods with them to their home countries. If goods are purchased in large quantity, traders give goods to cargo companies to ship. Payments are usually made in cash. In orders made by telephone or e-mail abroad, payments are made when the cargo is received. After a while, a certain amount of flexibility is shown to those who work regularly and those who have stores. On the basis of trust, goods are given to these people by taking some of the payment in cash and the rest through an open account. Usually in textile products $70 \%$ of payments are received in cash. In the suitcase trade, the payment is done without a bill. Payment is directed to personal accounts.

Some clients make their payments by hand to a courier who controls cargo procedures in the hotels. Cargo procedures are made according to distance either by ship, truck, bus or plane. Cargo is sent via planes to distant regions like Siberia. Cargo is also sent via ships to Ukraine and Lithuania. Cargo is sent by cargo companies who they have agreement traders.

\subsubsection{Foreign Suitcase Traders}

Participants indicated that almost all the same suitcase traders continued to trade after 1997. They also specified that in the last years citizens from African and Arab countries have also started to come. However, the participants stress that they only buy in small scales. They note that the products they buy are ready to wear clothes, shoes, accessories and leather products.

\subsubsection{Problems of Foreign Suitcase Traders}

Most participants indicated that citizens from Yugoslavia, Russia, Poland, Hungary, Romania and Ukraine encountered the most problems before the decline of the suitcase trade. Most participants indicated that after the decline of the suitcase trade citizens from Balkan countries and Georgia have also started to encounter problems.

Problems encountered generally are listed below:

1) Another product is sent instead of the product which was ordered.

2) A lower priced product is sent instead of the agreed upon product.

3) A defective product is sold or sent.

4) Custom procedures, taxes, stricter customs conditions.

5) Purse-snatching

6) Shopkeepers view clients as inferior

7) Customers opened stores in their neighborhoods and went into bankruptcy due to defective and less quality goods.

8) Problems related to national policies.

9) Greedy shopkeepers in Laleli.

10) Problems related to cargo and increases in cargo prices.

11) Products not sent in time. 


\subsubsection{The Problems of the Laleli Market}

Participants indicated that while previously purse-snatching and theft were major problems, today these problems have disappeared. However, they stressed that maltreatment of Turkish suitcase traders towards foreign suitcase traders, expensive cargo prices, high custom taxes, expensive hotel prices, accommodation problems and decreases in purchasing power constitute major problems in the Laleli market today.

\subsubsection{Policy Proposals with Regards to the Suitcase Trade}

The participants suggest that the rate of customs taxes should be decreased. The state should publicize Turkish goods abroad and lift visas with related countries. Turkish goods should compete with Chinese goods.

\section{Discussion and Conclusion}

By analyzing participant information, this study provided a clear and detailed picture of the general characteristics of the suitcase trade, the external factors which have impacted the suitcase trade, everyday experiences and culture-sharing behavior of suitcase traders and the changing dynamics of the suitcase trade. Official statistics, survey and focus group interviews give different results with regard to the decline of the suitcase trade. According to official statistics the suitcase trade started to decline from 1996 onwards. According to survey results, the year most participants associate with high intensity of the suitcase trade is 1997. According to focus group interviews, the suitcase trade started to decline in 1998 when Russia devalued its currency.

Differences with regard to the year in which the suitcase trade decline notwithstanding, this study aimed to explore how the changing dynamics of the suitcase trade have impacted Turkish suitcase traders. Participants indicated that before the decline of the suitcase trade more goods were manufactured. After the decline of the suitcase trade, citizens from African and Arab countries have also started to come. However, they indicated that compared to Russian citizens, they buy in smaller scales.

The distribution channel under the Soviet Union did not work efficiently due to its closed economy. The supply side of the distribution channels was completely under state control. When the economic transformation took place in the 1990s, distribution channels collapsed in the Russian Federation and the former Soviet Republics. This development played a major role in the increase of the suitcase trade between these countries and Turkey. With the disruption of supply chains in the transition period, the gap between the supply and the demand increased and the suitcase trade emerged as a lucrative business which met the consumption needs of Russian citizens. In parallel to these developments, the suitcase trade in Turkey increased between 1990 and 1997. Although the suitcase trade peaked at one-third of total Turkish exports in 1997, it significantly decreased afterwards.

The East Asian crisis in 1998 had a negative impact on the suitcase trade between the Russian Federation and Turkey. Due to the economic crisis, Russia devalued its currency. Therefore, Turkish products became more expansive for Russians. As a consequence, the suitcase trade between two countries declined dramatically. Quite the contrary, the East Asian crisis had a positive impact on the suitcase trade between South Korea and China. Due to an increase in unemployment after the economic crisis, the suitcase trade increased between the two countries.

It is important to note that consumption patterns are changing in Russia. Over the last ten years, the size of the middle class in Russia increased. Due to the policies of the Soviet Union, most Russians have their own houses. Furthermore, there is a state-controlled health-care system in Russia. Therefore, most Russians spend a significant amount of their budget on consumption and they choose expensive and high quality products rather than cheap and low quality products (Kramer, 2013).

In line with changing consumption patterns, trade patters are also changing in Russia. In order to meet the consumption needs of the Russian citizens, shopping malls were opened. The first shopping mall in Russia was opened in 2000. Today there are 82 shopping malls only in Moscow. Mega Tyoply Stan shopping mall in Moscow attracted 57 million visitors in 2007 (Briggs, 2012). With this infrastructure, retailers in shopping malls replaced suitcase traders.

In addition changing consumption patterns and trade dynamics in the Russian Federation, regional trade dynamics have impacted the Turkish suitcase trade. The route of the suitcase trade shifted towards North Africa such as Nigeria, Angola, Mauritania, Kenya, Somalia, Ethiopia South Africa and the Central Asia such as Kazakhstan, Tajikistan, Kyrgyzstan, Uzbekistan (Şahin, 2013).

The business environment for Turkish suitcase traders today is dynamic and highly competitive. Turkish suitcase trade products have to compete with Chinese products and have to be attractive to foreign citizens at the same 
time. In addition to competitive external environment, Turkish suitcase traders face domestic challenges such as expensive cargo prices, accommodation problems, low quality products and the like. In order to increase the competitiveness of Turkish goods businesses in the Laleli Market, suitcase traders should adapt themselves to changing consumption, production and trade patterns in the region. The Istanbul Chamber of Commerce in cooperation with Departments of Tourism Administration should deliver vocational courses for suitcase traders on foreign languages and cultures. Understanding foreign cultures and proficiency in languages may help suitcase traders advance their business interests. The Turkish government should encourage the suitcase trade by decreasing taxes on transportation, cargo business and accommodation.

\section{References}

Ahluwalia, M. S. (2002). Economic reforms in India since 1991: Has gradualism worked? Journal of Economic Perspectives, 16(3), 67-88. http://dx.doi.org/10.1257/ 089533002760278721

Baumol, W. J., \& Strom, R. J. (2007). Entrepreneurship and economic growth. Strategic Entrepreneurship Journal, (1), 233-237. http://dx.doi.org/10.1108/14626000410519173

Chung-Ming, L. (2011). Team and organizational resources, strategic orientations, and firm performance in a transition economy. Journal of Business Research, (64), 1344-1351. http://dx.doi.org/10.1016/j.jbusres.2011.01.001

Chung-Ming, L., Daphne, W. Y., Ping-Kwong, Y., \& Yuan, L. (2008). Strategic orientation of high-technology firms in a transitional economy. Journal of Business Research, (61), 765-777. http://dx.doi.org/10.1016/j.jbusres.2007.07.031

Dansc1, K. (2008). Towards a rights-based post-national Union: EU Integration and Schengen extension discourse 2003-2006 (Doctoral Dissertation, New Jersey State University, New Jersey, the USA). Retrieved from https://books.google.com.tr/books?id=C3Tc3CMquY4C\&printsec=frontcover\#v=onepage \&q\&f=false

Duman, M., \& Samadov, N. (2003). Türkiye ile Rusya Federasyonu Arasındaki İktisadi ve Ticari İlişkilerin Yapısı Üzerine Bir İnceleme. Kocaeli Üniversitesi Sosyal Bilimler Enstitüsü Dergisi, (6), 25-47.

Eder M., Yakovlev, A., \& Çarkoglu, A. (2003). Suitcase Trade Between Turkey and Russia: Microeconomics and Institutional Structure. Социология рынков.

Eder, M., \& Öz, Ö. (2010). From cross-border exchange networks to transnational trading practices? The case of shuttle traders in Laleli, İstanbul. In M. Djelic, \& S. Quack (Eds.), Transnational Communities: Shaping Global Economic Governance (pp. 82-105). Cambridge: Cambridge University Press.

Eder, M., \& Öz, Ö. (2008). Scrutinizing the Link between Poverty and Business Strategy: What Can We Learn from the Case of Shuttle Traders in Laleli, İstanbul. In C. Wankel (Ed.), Alleviating Poverty Through Business Strategy (pp. 123-148). Palgrave Macmillan. http://dx.doi.org/10.1057/9780230612068_7

Egbert, H. (2006). Cross-border Small-scale Trading in South-Eastern Europe: Do Embeddedness and Social Capital Explain Enough? International Journal of Urban and Regional Research, 30(2), 346-361. http://dx.doi.org/10.1111/j.1468-2427.2006. 00668.x

Firth, M., Tak, Y. L., Rui, O. M., \& Chaohong, N. (2015). Relative pay and its effects on firm efficiency in a transitional economy. Journal of Economic Behavior \& Organization, (110), 59-77. http://dx.doi.org/10.1016/j.jebo.2014.12.001

Fischer, S., \& Gelb, A. (1991). The process of socialist economic transformation. Journal of Economic Perspectives, (5), 91-105. http://dx.doi.org/10.1257/jep.5.4.91

Gao, G. Y., Zhou, K. Z., \& Yim, C. K. B. (2007). On what should firms focus in transitional economies? A study of the contingent value of strategic orientations in China. International Journal of Research in Marketing, (24), 3-15. http://dx.doi.org/10.1257/jep.5.4.91

Holtom, P. (2006). Shuttle Trade and New Border Regimes. Russian Regional Perspectives Journal, 1(3), 1-7. Retrieved

from http://www.iiss.org/publications/russian-regional-perspectives-journal/volume-1---issue-3/copy-of-shuttle-tr ade-and-new-border-regimes

Kaufmann, D. D., \& Shleifer, A. (1997). The Unofficial Economy in Transition. Brooking Papers on Economic Activity, (2), 159-221. Retrieved from http://www.brookings.edu/ /media/Projects/BPEA/1997-2/1997b_bpea_johnson_kaufmann_shleifer_goldm an_weitzman.PDF 
Kornai, J. (1986). The Hungarian reform process: Visions, hopes, and reality. Journal of Economic Literature, (24), 1687-1737. http://dx.doi.org/10.1016/j.jwb.2014.05.004

Kucukaltan, D. (2006). Tourism and Terrorism: An Experience of Turkey and the World. iUniverse, Inc.

Naude', W. (2011). Entrepreneurship is not a binding constraint on growth and development in the poorest countries. World Development, (39), 33-44. http://dx.doi.org/10.1016/j.ibusrev.2013.12.004

Nelson, R. R. (2008). What enables rapid economic progress: What are the needed institutions? Research Policy, (37), 1-11. http://dx.doi.org/10.1016/j.respol. 2007.10.008

Ramamurti, R. (2000). A multilevel model of privatization in emerging economies. Academy of Management Review, (25), 525-550. http://dx.doi.org/10.1017/mor.2015.30

Rinaldi G. (2008). The size of the firm in a transitional economy: Downsizing and economies of scale: The case of Russian footwear. Economic Systems, (32), 389-409. http://dx.doi.org/10.1016/j.ecosys.2008.01.002

Sahin, A., Akdi, Y., \& Atakan, C. (2008). An Investigation on the Shuttle Trade Dynamics of a Small-Open-Economy. International Journal of Economic Sciences and Applied Research, 1(2), 1-12. http://dx.doi.org/10.1080/00263206.2011.591169

Schneider, F., \& Enste, D. (2002). Hiding in the Shadows: The Growth of the Underground Economy. IMF Economic Issues, (30). Retrieved from www.imf.org/external/pubs/ft/issues/issues30/

Stammler-Gossmann, A. (2012). Winter-Tyres-for-a-Flower-Bed: Shuttle Trade on the Finnish Russian Border. In B. Bruns, \& J. Miggelbrink (Eds.), Subverting Borders: Doing Research on Smuggling and Small-Scale Trade. Wiesbaden: Springer VS. http://dx.doi.org/10.1007/978-3-531-93273-6

Xinxiang, C. (2010). Modes of state intervention and business group performance in China's transitional economy. The Journal of Socio-Economics, 39, 619-630. http://dx.doi.org/10.1016/j.socec.2010.06.006

Yükseker, D. (2004). Trust and Gender in a Transnational Market: The Public Culture of Laleli. Istanbul, Public Culture, 16(1), 47-65. http://dx.doi.org/10.1215/08992363-16-1-47

Yükseker, D. (2007). Shuttling Goods, Weaving Consumer Tastes: Informal Trade between Turkey and Russia. International Journal of Urban and Regional Research, 31(1), 60-72. http://dx.doi.org/10.1111/j.1468-2427.2007.00710.x

Central Bank of Turkey. (December 2014). Turkey's Payment Balance Statistics. Retrieved from http://www.tcmb.gov.tr/wps/wcm/connect/TCMB+TR/TCMB+TR/Main+Menu/Istatistikler/Odemeler+Den gesi+ve+Ilgili+Istatistikler/Odemeler+Dengesi+Istatistikleri/Odemeler+Dengesi+Gelismeleri

International Monetary Fund. (1998). Shuttle Trade. Eleventh Meeting of the IMF Committee on Balance of Payments Statistics. Retrieved from https://www.imf.org/external/bopage/pdf/98-1-3.pdf

Briggs, F. (2012). Ikea's Mega shopping malls are gateway for western retailers to enter Russia. Retail Times. Retrieved from http://www.retailtimes.co.uk/tag/ikea-shopping-centres-russia/

Kramer, E. A. (2013). Malls Blossom in Russia, With a Middle Class. New York Times. Retrieved from http://www.nytimes.com/glogin?URI=http\%3A\%2F\%2Fwww.nytimes.com\%2F2013\%2F01\%2F02\%2Fbus iness\%2Fglobal\%2Fwith-a-mall-boom-in-russia-property-investors-go-shopping.html\%3F_r\%3D0

Yavuz, E. (2010). Turkey, Russia lifting barriers to shuttle trade. Today's Zaman. Retrieved from http://www.todayszaman.com/business_turkey-russia-lifting-barriers-to-shuttle-trade_198844.html

\section{Copyrights}

Copyright for this article is retained by the author(s), with first publication rights granted to the journal.

This is an open-access article distributed under the terms and conditions of the Creative Commons Attribution license (http://creativecommons.org/licenses/by/3.0/). 